\title{
ЗДОРОВ’Я ЛЮДИНИ, ФІТНЕС І РЕКРЕАЦІЯ. ФІЗИЧНЕ ВИХОВАННЯ РІЗНИХ ГРУП НАСЕЛЕННЯ. ФІЗИЧНА РЕАБІЛІТАЦІЯ
}

\section{ДИНАМІКА МОРФОФУНКЦІОНАЛЬНИХ ПОКАЗНИКІВ ХЛОПЦІВ ВІКОМ 10-13 РОКІВ ПІД ВПЛИВОМ ЗАНЯТЬ РІЗНИМИ ВИДАМИ ТУРИЗМУ}

\section{Тетяна Гриньова}

\begin{abstract}
Резюме. Рассмотрено развитие морфофрункциональных показателей мальчиков, занимающихся пешеходным, велосипедным и водным видами туризма, а также мальчиков, не занимающихся в спортивных секциях. В исследовании участвовало по 18 мальчиков в возрасте 10-13 лет в каждой из групп. Определено, что тренировочные нагрузки не влияют на показатели фризического развития, которые изменяются в соответствии с развитием организма детей, в отличие от показателей фрункциональной системы. Наиболее существенное влияние занятия туризмом оказывают на показатели сердечно-сосудистой и дыхательной систем у мальчиков, которые занимались велосипедным туризмом, а наименьшее - водным. Ключевые слова: морфофункциональные показатели, виды туризма, динамика.
\end{abstract}

Summary. The paper scrutinizes development of morpho-functional indices in boys engaged in different types of outdoor activities such as hiking, cycling and canoeing, as well as the boys, who didn't take part in sport sections. The study involved eighteen 10-13 years old boys in each group. It was found that the training loads don't influence the indices of physical development that change in accordance with the development of child's body unlike the indices of the functional system. The most substantial influence of outdoor activity was detected on the indices of the cardiovascular and respiratory systems in the group of boys engaged in cycling, and the least in the group engaging in fresh water activities.

Key words: morpho-functional indices, types of outdoor recreational activities, dynamics.

Постановка проблеми. Аналіз останніх досліджень і публікацій. Регулярні заняття різними видами фізичної культури, спорту, зокрема і туризму, позитивно впливають на основні фізіологічні показники. Вивченням питання впливу туризму на організм людини займалися такі дослідники, як А. Н. Бурових [1], В. М. Селуянов, А. А. Федякін [7], О. Л. Жигарев [2], Є. 3. Рут [6] та ін. В існуючих дослідженнях встановлено поліпшення функціонального стану кардіореспіраторної системи, яке проявляється у збільшенні ударного об'єму крові, та потужності вдиху і видиху навіть під впливом одноразових багатоденних походів [3]. Проведені дослідження щодо впливу використання елементів спортивно-оздоровчого туризму у фізичному вихованні студентів та школярів на рівень їх фізичного стану показали позитивний ефект. Так, у студентів покращилися показники маси тіла, артеріального тиску (АТ), частоти серцевих скорочень (ЧСС) та відновлюваності пульсу [2, 4, 6, 8, 9].

В науковій літературі встановлено, що пішохідний, велосипедний та водний види туризму ма- ють неоднаковий вплив на організм туристів [3, 5]. Проте досліджень впливу систематичних занять кожним видом туризму на організм дітей не виявлено. Враховуючи специфіку кожного виду для занять водним туризмом найкращим є період 3 травня по вересень, велосипедним - 3 квітня по листопад. Решта часу приділяється фізичній підготовці, на відміну від пішохідного туризму, яким можна займатися протягом усього року. 3 проведеного нами анкетування було визначено, що діти хочуть займатися не якимсь конкретно видом туризму, а поєднувати заняття із різних видів. Тому виникла потреба розробки програми, яка буде включати поєднані заняття з пішохідного, велосипедного та водного видів туризму.

Дослідження виконано згідно 3 тематичним планом науково-дослідної роботи у сфері фізичної культури і спорту на 2011-2015 pр. за темою 3.8 "Теоретико-методологічні основи побудови системи масового контролю і оцінки рівня розвитку і фізичної підготовленості різних груп населення" (номер держреєстрації 0111U000192). 


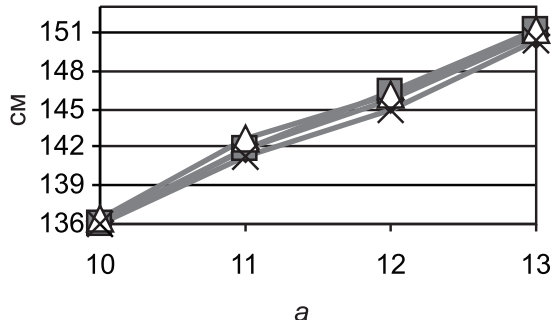

$a$
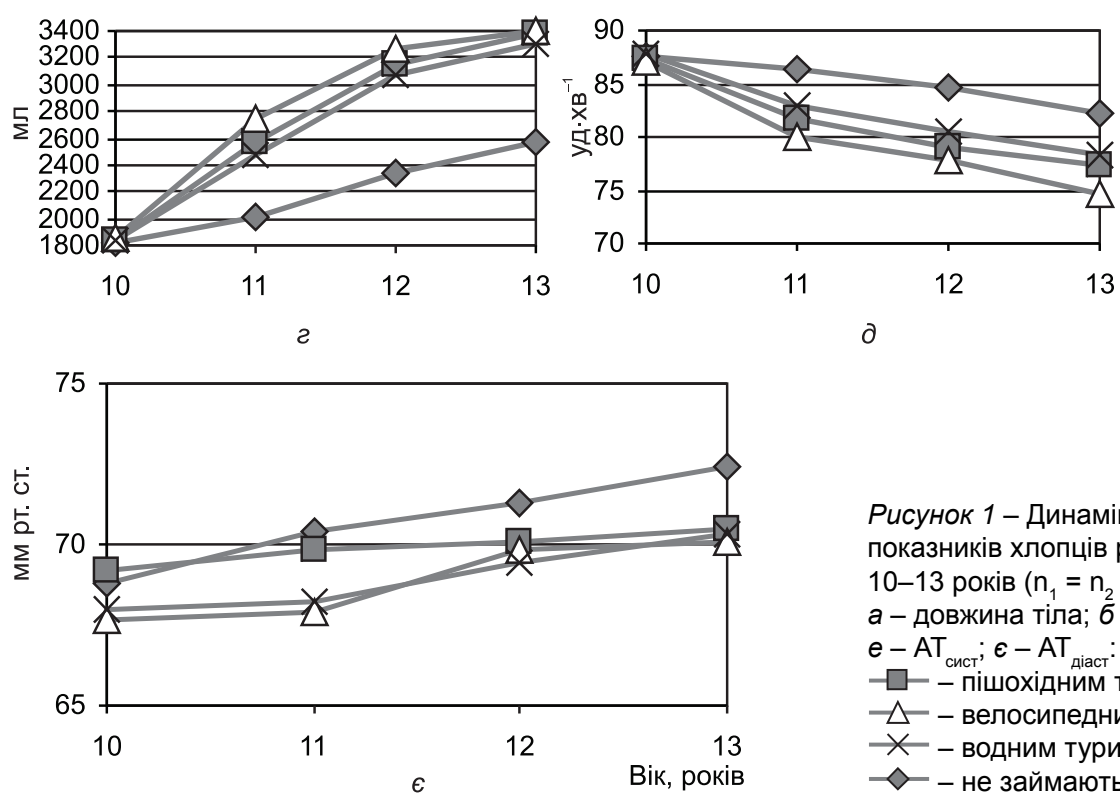

Мета дослідження - визначити динаміку показників морфофункціонального розвитку хлопців віком 10-13 років під впливом занять різними видами туризму.

Методи та організація дослідження: аналіз й узагальнення науково-методичної літератури, медико-біологічні методи; методи математичної статистики.

В дослідженні взяли участь 54 хлопця-вихованця віком 10-13 років гуртків із пішохідного, велосипедного та водного видів туризму Чугуївського районного центру туризму, краєзнавства та екскурсій учнівської молоді упродовж трьох років занять, а також 18 хлопців цього ж віку, які не займалися у спортивних секціях.

Заняття із різних видів туризму проводились за типовими програмами туристсько-спортивних гуртків, за якими передбачається 216 год за рік: 2 заняття на тиждень тривалістю 3 год кожне.

Результати дослідження та їх обговорення. Проведене нами дослідження морфофункціональних показників під впливом занять різними видами туризму свідчить, що тренувальні навантаження не впливають на зміни показників довжини тіла та окружності грудної клітки (ОГК) хлопців віком 10-13 років, а змінюються відповідно до розвитку організму. Так, показник довжини тіла у $e-\mathrm{AT}_{\text {сист }} ; \epsilon-\mathrm{AT}_{\text {діаст }}$ :
Рисунок 1 - Динаміка розвитку морфофункціональних показників хлопців різних експериментальних груп віком 10-13 років $\left(\mathrm{n}_{1}=\mathrm{n}_{2}=\mathrm{n}_{3}=\mathrm{n}_{4}=18\right)$, які займаються: а - довжина тіла; б - ОГК; в - маса тіла; г - ЖєЛ; д - ЧСС;

$\square--$ пішохідним туризмом;

$\triangle-$ велосипедним туризмом;

$\times-$ водним туризмом

$\checkmark-$ не займаються у спортивних секціях;

хлопців з усіх груп у період 10-11 років збільшився у середньому на 5,5 см $(\mathrm{p}<0,05-0,01), 11-12$ років - на 3,9 см (p < 0,05-0,01) 12-13 років - на 5,0 см $(\mathrm{p}<0,001)$. У цілому ж за 3 роки довжина тіла хлопців в усіх групах у середньому збільшилась на 14,6 см (р < 0,001) (рис. $1 a)$.

Найбільший приріст показника ОГК спостерігається в усіх групах хлопців віком 10-11 років і в середньому становить 2,9 см ( $<<0,05-0,01)$, а найменший - 1,2 см у хлопців віком 12-13 років $(\mathrm{p}>0,05)$ (рис. 1 б). Упродовж експерименту показники ОГК збільшились у хлопців, які не займалися у спортивних секціях на 6,9 см, у туристів-пішохідників - на 5,9 см, у туристів-велосипедистів та водників - на 6,5 см ( $<<0,001)$.

Спостерігається незначний вплив занять туризмом на показник маси тіла (рис. 1 в). На початку експерименту різниці між групами туристів та групою хлопців, які не займаються у спортивних секціях, не виявлено, проте після першого року занять і до кінця експерименту різниця коливається у межах 2-3 кг.

Найбільший приріст показника маси тіла у групі хлопців, які не займаються спортом, спостерігається у період 10-11 років і становить 3,0 кг $(\mathrm{t}=2,04 ; \mathrm{p}>0,05)$, у групі туристів-пішохідників в період 12-13 років $-2,8$ кг $(\mathrm{t}=1,98 ; \mathrm{p}>0,05)$, 
у цей же віковий період у групі туристів-велосипедистів - 4,0 кг $(\mathrm{t}=2,57 ; \mathrm{p}<0,05)$ та у групі туристів-водників - 3,5 кг $(\mathrm{t}=2,46 ; \mathrm{p}<0,05)$.

За весь період експерименту показник маси тіла у хлопців, які не займалися в спортивних секціях, збільшився на 8,3 кг $(\mathrm{t}=6,01 ; \mathrm{p}<0,001)$, у хлопців, які займаються пішохідним туризмом, на 5,9 кг $(\mathrm{t}=5,55 ; \mathrm{p}<0,001)$, у хлопців, які займаються велосипедним туризмом, - на 6,4 кг $(\mathrm{t}=5,36 ; \mathrm{p}<0,001)$ та у групі туристів-водників - на 6,9 кг $(t=6,64 ; \mathrm{p}<0,001)$.

Нами виявлено значну різницю показників життєвої ємності легень (ЖЕЛ) між хлопцями, які не займалися у спортивних секціях та групами туристів, що свідчить про позитивний вплив занять туризмом на стан дихальної системи за рахунок використання вправ на розвиток витривалості (рис. 1 2). Так, у хлопців, які не займалися в спортивних секціях найбільший приріст цього показника було визначено у 11-12 років, який становить 335,6 мл $(\mathrm{t}=3,74 ; \mathrm{p}<0,01)$, а туристів найбільший приріст показника ЖЕЛ був визначений у віці 10-11 років. Так, у туристів-пішохідників показник ЖЕЛ збільшився на 730,6 мл $(\mathrm{t}=12,09$; $\mathrm{p}<0,001)$, туристів-велосипедистів - на 898,0 мл $(\mathrm{t}=14,18 ; \mathrm{p}<0,001)$ та туристів-водників - на 636,5 мл $(\mathrm{t}=13,54 ; \mathrm{p}<0,001)$.

За три роки у хлопців, які не займалися у спортивних секціях, результати ЖЕЛ збільшились на 750 мл $(\mathrm{t}=7,16 ; \mathrm{p}<0,001)$, у хлопців, які займались пішохідним туризмом, - на 1533,4 мл $(\mathrm{t}=28,18 ; \mathrm{p}<0,001)$, хлопців, які займались велосипедним туризмом, - на 1544,4 мл $(\mathrm{t}=28,24$; p < 0,001) та хлопців, які займались водним туризмом, - на 1455,5 мл $(\mathrm{t}=25,91 ; \mathrm{p}<0,001)$.

Порівнюючи показники частоти серцевих скорочень (ЧСС), виявлено, що за період експерименту цей показник найбільше покращився у хлопців, які займалися велосипедним туризмом за рахунок роботи на розвиток витривалості (рис. 1 д).
Так, за три роки занять у туристів-велосипедистів показник ЧСС зменшився на 12,5 уд $\mathrm{xB}^{-1}$ $(\mathrm{t}=13,76 ; \mathrm{p}<0,001)$, у туристів-пішохідників на 9,8 уд $\mathrm{xB}^{-1}(\mathrm{t}=7,78 ; \mathrm{p}<0,001)$, у туристів-водників - на 9,3 уд $\mathrm{xB}^{-1}(\mathrm{t}=9,50 ; \mathrm{p}<0,001)$ та у хлопців, які не займалися у спортивних секціях, - на 5,3 уд $\mathrm{xв}^{-1}(\mathrm{t}=5,30 ; \mathrm{p}<0,001)$.

Незначну різницю було визначено у динаміці показників артеріального тиску - AT (рис $1 e$, $\epsilon$ ). У хлопців, які не займалися у спортивних секціях, показники найвищі, проте знаходяться у межах норми, гіпертонічних проявів визначено не було.

Отримані результати свідчать про більший позитивний вплив занять велосипедним та пішохідним туризмом на стан серцево-судинної системи дітей.

\section{Висновки:}

1. Заняття туризмом позитивно впливають на морфофункціональні показники юних туристів.

2. Тренувальні навантаження не впливають на показники фізичного розвитку (довжина тіла, маса тіла, ОГК), а змінюються відповідно до розвитку організму дітей, на відміну від показників функціональної системи.

3. Найбільш суттєвий вплив занять туризмом відмічено у показниках кардіореспіраторної системи у хлопців, які займалися велосипедним туризмом, а найменші - водним. Так, у хлопців, які займались велосипедним туризмом, показники ЧСС зменшились на $14 \%(\mathrm{t}=13,76 ; \mathrm{p}<0,001)$, а у хлопців, які займались водним туризмом, - на $10 \%(\mathrm{t}=9,50 ; \mathrm{p}<0,001)$. Показники ЖСЛ збільшились на $83 \%(t=28,24 ; \mathrm{p}<0,001)$ та $79 \%$ $(\mathrm{t}=25,91 ; \mathrm{p}<0,001)$ відповідно.

Перспективи подалыших досліджень полягають у визначенні впливу занять різними видами туризму на рівень здоров'я дітей і на основі отриманих результатів розробити комплексну програму зі спортивного туризму.

\section{Література}

1. Буровых А. Н. Изменение отдельных показателей функционального состояния организма в ходе туристского похода / А. Н. Буровых // Роль и задачи спортивно-массового туризма в фризическом воспитании и оздоровлении населения: [тез. докл. ]. - М., 1990. - С. 109-110.

2. Жигарев О. Л. Влияние спортивно-оздоровительного туризма на морфофункциональные и психофизиологические показатели организма студентов: автореф. на соискание учен. степени канд. биол. наук: спец. 03. 00. 13 «Физиология» / О. Л. Жигарев. - Новосибирск, 2002. - 24 с.

3. Курилова В. И. Туризм: [учеб. пособие для студ. пед. ин-тов по спец. № 2114 «Физ. воспитание» и № 2115 «Нач. воен. обучение и физ. воспитание»] / В. И. Курилова. - М.: Просвещение, 1988. - 224 с.

4. Кухтій О. А. Вплив пішохідного туризму на функціональний стан організму студентів (на прикладі спеціальності «Туризм») / О. А. Кухтій // Наук. часопис Нац. пед. ун. ім. М. П. Драгоманова: [зб. наук. пр.]. К.: НПУ ім. М. П. Драгоманова, 2011. - № 13. - С. 290-294.

5. Никишин Л. Ф. Туризм и здоровье / Л. Ф. Никишин, А. А. Коструб. - К.: Здоров'я, 1991. - 222 с.

6. Руm €. 3. Організаційно-методичні основи туристсько-краєзнавчої діяльності в школі та її вплив на організм школярів : автореф. дис. на здобуття наук. ступеня д-ра наук з фріз. вих і спорту: спец. 24.00.02 «Фізична культура, фрізичне виховання різних груп населення» / Є. З. Рут. - Х., 2005. - 38 с. 
7. Селуянов В. Н. Биологические основы оздоровительного туризма: монография / В. Н. Селуянов, А. А. Федякин. - М.: СпортАкадемПресс, 2000. - 123 с.

8. Семерунь В. З. Використання самодіяльного оздоровчого туризму як засобу зміцнення здоров'я та фрізичного удосконалення студентства аграрних ВН3 / В. 3. Семерунь, С. І. Присяжнюк // Здоров'я і освіта: проблеми та перспективи: матеріали III Всеукр. наук.-практ. конф. [ред.кол.: А. Г. Рибковський (голов. ред.) та ін.]. - Донецьк: ДонНУ, 2004. - С. 302-307.

9. Шавель X. Є. Морфофункціональний стан та фрізична працездатність студентів-учасників туристичних мандрівок / X. Є. Шавель, І. І. Сосонка // Туризм і краєзнавство: зб. наук. пр. - Додаток до Гуманіт. вісн. ДВНЗ «Переяслав-Хмельницький державний педагогічний університет ім. Г. Сковороди». - ПереяславХмельницький, ПП «СКД», 2012. - С. 363-367.

\section{References}

1. Burovykh A. N. Changes in some indices of functional state of the body during tourist trip / A. N. Burovyh // Role and tasks of sports-mass tourism in physical education and health improvement : [abstracts of the reports]. Moscow, 1990. - P. 109-110.

2. Zhigarev O. L. Influence of sport and recreational tourism on morpho-functional and psychophysiological indices of students' body : autoref. of dis. for the degree of Cand. of Sci. in biology / O. L. Zhigarev. - Novosibirsk, 2002. $-24 \mathrm{p}$.

3. Kurilova V. I. Tourism : [study guide for ped. inst.] / V. I. Kurilova. - Moscow, 1988. - 224 p.

4. Kukhtii A. O. Influence of hiking on the functional state of students' body (as exemplified by the speciality "Tourism") / A. O. Kukhtii // Naukovyi chasopys M. P. Dragomanov National Pedagogical University. - 2011. N 13. - P. 290- 294.

5. Nikishin L. F. Tourism and health / L. F. Nikishin, A. A. Kostrub. - Kiev: Zdorovia, 1991. - 222 p.

6. Root J. Z. Organizational-methodical bases of tourist-country study activity at the school and its influence on the school students' body : autoref. of dis. for the degree of Dr. of Sci. in physical culture and sports : spec. 24.00.02 "Physical culture, physical education of different groups of population» / J. Z. Root. - Kharkiv, 2005. $38 \mathrm{p}$.

7. Seluianov V. N. Biological foundations of recreational tourism : monograph / V. N. Seluianov, A. A. Fediakin. Moskow: SportAkademPress, 2000. - 123 p.

8. Semerun $V$. Z. The use of amateur recreational tourism as a mean of health and physical improvement for students of agrarian higher educational institutions / V. Z. Semerun, S. I. Prysiazhniuk // "Health and education: problems and perspectives": Materials of III All-Ukrainian scient. and pract. conf. - Donetsk, 2004. - P. 302-307.

9. Shavel Kh. Ye. Morpho-functional state and physical performance students-participants of tourist journeys / Kh.Ye. Shavel, I. Sosonka // Tourism and regional ethnography: collection of scientific works. - PereiaslavKhmelnytskyi, 2012. - P. 363-367. 